\title{
Constraints Perceived by the Cotton Growers on the Cotton Cultivation in Kurnool District of Andhra Pradesh, India
}

\author{
E. Ravi Goud*, Daya Ram and K. Raghavendra Chowdary \\ College of Agriculture, Central Agricultural University, Imphal-795004, Manipur, India \\ Krishi Vigyan Kendra, Banavasi-518360, Andhra Pradesh, India \\ *Corresponding author
}

Ke y w o r d s
$\begin{aligned} & \text { Technological, Bio- } \\ & \text { physical, Socio- } \\ & \text { economic, Marketing and } \\ & \text { Institutional constraints, } \\ & \text { Garrett ranking method }\end{aligned}$
Article Info
$\begin{aligned} & \text { Accepted: } \\ & \text { 06 May } 2018 \\ & \text { Available Online: } \\ & \text { 10 June } 2018\end{aligned}$

10 June 2018

\section{A B S T R A C T}

A study was conducted in Kurnool district of Andhra Pradesh with the objective of studying the constraints perceived by the cotton growers, with a sample size of 120 respondents. In this study, respondents were asked to rank their preferences which they perceived more by using Garrett Ranking Method. The constraints were categorized into technological, bio physical, socio-economic, marketing and institutional constraints. Under technological, insufficient training programs $(63.00 \%)$ was the major problem, followed by Inadequate irrigation facilities $(65.70 \%)$ was the leading problem in bio-physical constraints, high cost of chemical inputs $(63.62 \%)$ in the socio-economic constraints, lack of remunerative prices $(62.70 \%)$ under the marketing constraints and Lack of proper storage facilities $(67.75 \%)$ was the major problem under the institutional constraints. These findings draw attention of extension workers, researchers and policy makers. At research level action can be initiated for the introduction of ideal cotton varieties with short duration, compact plant types with high harvest index resistant/tolerant to biotic and abiotic stress and amenable for mechanical picking and resistance to pest and diseases, at policy level action can be initiated on promoting one variety communities, seed villages, storage facilities, community plant protection and protective irrigation and at extension level more training for farmer groups to create awareness on latest production technologies in cotton.

\section{Introduction}

Cotton is the backbone of Indian textile industry, which consumes $59 \%$ of the country's total fiber production. It accounts for $34 \%$ of the country's export and fetches about Rs.50,000 cores annually to the exchequer. Along with the industry, which it sustains, it touches the country's economy at several points including employment and export earnings. India having the largest area under cotton cultivation in the world ranging between 10.9 million hectares to 12.8 million hectares and constituting about $38 \%$ to $41 \%$ of the world area under cotton cultivation (cotcorp.gov.in) Around 6 to 6.5 million farmers grow the crop in about 10 States (Punjab, Haryana, Rajasthan, Gujarat, Madhya Pradesh, Maharashtra, Andhra Pradesh, Telangana, Karnataka and Tamil Nadu). Around 60 million people are estimated to depend on it one way or the other to make out 
their living (cotcorp.gov.in). Government of India implemented many programs and policies to overcome the problems of the farmers in general and cotton crop in specific, but still many cotton growers committed suicides. Therefore, study was conducted to know what are the major constraints faced by cotton growers during cotton cultivation. Hence, constraints are the important bilateral indicators for growth and development of agriculture in general and cotton crop in specific. Keeping this in view, the present study was taken up to study the constraints of the cotton growers.

\section{Materials and Methods}

The present study was conducted during the year 2016-17 by the following Ex-Post-Facto research design with objective of studying the constraints perceived by the cotton growers. The investigation was carried out in Kurnool district of Andhra Pradesh was purposively selected as it stands first in area and production of cotton. Out of 54 mandals, three mandals namely Adoni, Pattikonda and Nandyal were purposively selected based on area and highest production.

From each selected mandal, four villages were selected by using simple random sampling method and from each selected village ten cotton growers were selected by using random sampling method $(12 \times 10=120)$ thus making a total sample size around 120. There are various constraints listed (technological, biophysical, socio-economic, marketing and institutional) to reflect the problems of cotton growers. For this study we selected Garrett's ranking method to find out the most significant factor which influences the respondent. The orders of merit given by the respondents were converted in to rank by using the formula. As per this method, respondents are allowed to rank their preferences on which they perceived more and the outcomes of such ranking have been converted into score value with the help of the following formula:

Percent Position $=100($ Rij -0.5$) / \mathrm{Nj}$

Rij $=$ Rank given for $i^{\text {th }}$ item by the $j^{\text {th }}$ sample respondents

$\mathrm{Nj}=$ Total rank given by $\mathrm{me} \mathrm{j}^{\text {th }}$ sample respondents

With the help of Garrett's Table, given by Garett and Woodworth (1969), the percent position estimated is converted into scores.

Then for each factor, the scores of each individual are added and then total value of scores and mean values of score is calculated. The factors having highest mean value is considered to be the most important factor (Dhanavandan, 2016).

\section{Results and Discussion}

\section{Technological constraints}

Table 1, shows that, Insufficient training programs $(63.00 \%)$ was the major perceived constraint, followed by Lack of awareness about market prices (54.79\%) and lack of knowledge about the recommended doses of insecticides/pesticides (49.79), Lack of knowledge about improved scientific practices in cotton crop (45.91\%) and availability of research stations $(45.66 \%)$ are the major leading problems under technological constraints.

Reason behind the insufficient training programs was, in Kurnool district most of the research stations (KVKs, DAATTCs, and Regional research stations) are located at far away from the cotton growing areas. These findings are line with results of Gohil et al., (2016) and Shelke and Kalyankar (2004). 


\section{Bio-physical constraints}

It was revealed that, Inadequate irrigation facilities $(65.70 \%)$ was the most important constraint perceived by the cotton growers, followed by incidence of insect pest and diseases $(64.75 \%)$, following poor spraying methods $(62.70 \%)$ and non-availability of quality seeds $(58.08 \%)$, and high cost of the seeds $(55.04 \%)$ among the total cotton growers. Generally study area had more dry spells than other parts of the state and they were only depends on monsoons, that's what most of the farmers expressed irrigation was the major problem. About $64.75 \%$ of the respondents said their farms were attacked by aphids, bacteria blight (Xanthmonas malvacearum) and alternaria leaf spot (Alternaria macopora), the spread of these two diseases is capable of destroying an entire cotton crop. These results are line with the results of Adeniji (2007), Bheemappa et al., (2004) and Chowdry (1998).

\section{Socio-economic constraints}

Table 1, found that high cost of chemical inputs $(63.62 \%)$ was the major problem, followed by Labour scarcity and high labour charges (62.66\%), non-availability of credit/loan facilities at peak period (51.45\%), non-availability of agricultural equipment $(51.16 \%)$ and non-availability of pesticides / fungicides when needed (47.62\%). Most of the operations involved in cotton production are still being done manually and of these harvesting and weeding appears to be the most labour intensive. These findings are line with results of Gohil et al., (2016) and Ahmad et al., (2016).

\section{Marketing constraints}

It was reported that, Lack of reasonable support prices $(62.70 \%)$ was major problem perceived under the marketing constraints, followed by high involvement of middle men $(59.00 \%)$, and Fluctuating market prices $(58.04 \%)$, Lack of marketing intelligence (56.54\%), and Lack of marketing and cooperative societies $(53.70 \%)$. Most of them suffer in the hands of unscrupulous middle men who often exploit and rob them of benefits of their effort. The problem is compounded because of lack of interference by government on matters affecting marketing and pricing of cotton. Better marketing prices are the essential to reduce the farmer's suicides in the southern parts of India. These findings are line with results of Gohil et al., (2016) and Drulson (2011).

\section{Institutional constraints}

Table 1, shows that Lack of proper storage facilities $(67.75 \%)$ was the major problem, followed by distance of farmers related institutions (66.29\%), Imperfect policy implementations (64.33\%), Ineffective extension system (59.75\%) and Lack of coordination among the line departments $(54.08 \%)$.

Under institutional constraints most of the cotton growers were facing lack of storage facilities; due to this problem most of the cotton growers were selling their produce in to markets immediately after picking. These findings are more or less line with the findings of Ahmad et al., (2016).

\section{Recommendations}

On the basis of study, following Suggestions to obviate the constraints faced by the growers in cotton cultivation:

It is vital to decrease the prices of inputs and machinery and development of indigenous transgenic varieties is one of the prime ways of reducing cultivation costs for the resourcepoor conditions of rain fed areas. 
Table.1 Constraints perceived by the cotton growers on the cotton cultivation

\begin{tabular}{|c|c|c|c|c|}
\hline $\begin{array}{l}\text { Sl. } \\
\text { No }\end{array}$ & $\begin{array}{l}\text { Constraints Perceived by the Cotton Growers on } \\
\text { the Cotton Cultivation }\end{array}$ & G.S & A.S & Rank \\
\hline \multicolumn{5}{|c|}{ Technological Constraints } \\
\hline 1. & $\begin{array}{l}\text { Lack of knowledge about improved scientific practices } \\
\text { in cotton crop }\end{array}$ & 5510 & 45.91 & IV \\
\hline 2. & Insufficient training programmes & 7560 & 63.00 & I \\
\hline 3. & $\begin{array}{l}\text { lack of knowledge about the recommended doses of } \\
\text { insecticides/pesticides }\end{array}$ & 5975 & 49.79 & III \\
\hline 4. & Lack of awareness about market prices & 6575 & 54.79 & II \\
\hline 5. & Availability of research stations & 5480 & 45.66 & V \\
\hline \multicolumn{5}{|c|}{ Bio-physical Constraints } \\
\hline 1. & Non-availability of quality seeds & 6970 & 58.08 & IV \\
\hline 2. & Inadequate irrigation facilities & 7885 & 65.70 & I \\
\hline 3. & Incidence of insect pest and disease & 7770 & 64.75 & II \\
\hline 4. & High cost of seeds & 6605 & 55.04 & V \\
\hline 5. & Practicing poor spraying methods & 7525 & 62.70 & III \\
\hline \multicolumn{5}{|c|}{ Socio-economic Constraints } \\
\hline 1. & Labour scarcity and high labour charges & 7520 & 62.66 & II \\
\hline 2. & High cost of chemical inputs & 7635 & 63.62 & I \\
\hline 3. & Non availability of credit/loan at peak period & 6175 & 51.45 & III \\
\hline 4. & Non-availability of agricultural equipment & 6140 & 51.16 & IV \\
\hline 5. & $\begin{array}{l}\text { Non-availability of pesticides and fungicides when } \\
\text { needed }\end{array}$ & 5715 & 47.62 & V \\
\hline \multicolumn{5}{|c|}{ Marketing Constraints } \\
\hline 1. & Labour scarcity and high labour charges & 7520 & 62.66 & II \\
\hline 2. & High cost of chemical inputs & 7635 & 63.62 & I \\
\hline 3. & Non availability of credit/loan at peak period & 6175 & 51.45 & III \\
\hline 4. & Non-availability of agricultural equipment & 6140 & 51.16 & IV \\
\hline 5. & $\begin{array}{l}\text { Non-availability of pesticides and fungicides when } \\
\text { needed }\end{array}$ & 5715 & 47.62 & V \\
\hline \multicolumn{5}{|c|}{ Institutional Constraints } \\
\hline 1. & Lack of proper storage facilities & 8130 & 67.75 & I \\
\hline 2. & $\begin{array}{l}\text { Distance of farmers related institutions (KVKs, } \\
\text { ATMA, ATIC, DAATTCs, AO office etc.) }\end{array}$ & 7955 & 66.29 & II \\
\hline 3. & Ineffective extension system & 7170 & 59.75 & IV \\
\hline 4. & Lack of co-ordination among the line departments & 6490 & 54.08 & V \\
\hline 5. & Imperfect policy implementations & 7720 & 64.33 & III \\
\hline
\end{tabular}

*G.S-Garrett Score, *A.S-Average Score

Government should take efforts to reduce cost of cultivation through stabilizing prices of critical inputs like seed, pesticide and herbicides. It is essential to strengthen the linkage between extension agent and farmer to provide technical assistance for pest scouting, knowledge about hazardous effects of chemicals and information about safe and proper use of chemicals. 
It is essential to strengthen linkages between research and extension for effective dissemination and adoption of latest production technologies by the cotton growers. There is a need to develop effective marketing and cooperative societies through creation of infrastructure facilities for better marketing of the farmers produce.

Provision of Institutional support in the form of credit and storage facilities at peak period and eliminate the distress sales.

Increased access to modern scientific ideas, ICT tools for farmers to get maximum benefits of scientific ideas, to adopt all the innovative practices (i.e. cotton expert systems) as a package or bundle.

\section{Acknowledgment}

The authors acknowledge the contributions of E. Ravi Goud, Daya Ram and K. Raghavendra Chowdary. College of Agriculture, Central Agricultural University, Imphal, Manipurand Krishi Vigyan Kendra, Banavasi, Andhra Pradesh for their technical support and valuable contributions to the manuscript.

\section{References}

Adeniji, O.B. (2007). Constraints to Improved Cotton Production in Katsina State, Nigeria. Journal of Applied Sciences, 7:1647-1651.

Ahmad A. K, Ijaz Ashraf, Gulfam, H., and Saleem, A. (2016). On Farm Analysis of Cotton Growers Handicaps: Evidence from Cotton Belt of Pakistan, International Journal of Agricultural Extension, 04 (01):79-85.
Anonymous. (2017). Status Paper of Indian Cotton, Directorate of Cotton Development, Government of India, Nagpur.13-14.

Bheemappa, A., Hirevenkanagoudar, L. V. and Chandargi, D. M., (2004). Analysis of constraints in adoption and reinvention of cotton production technology by the farmers of Tungabhadra command area, Karnataka. Paper presented in the Symposium Strategies for Sustainable Cotton Production - A Global Vision; held at the Univ. Agric. Sci., Dharwad from 23-25th November 2004.

Chowdry, K.R. (1998) Farmers Suicides in Andhra Pradesh, AWARE Development Research Advisory Group, Hyderabad.

Dhanavandan, S. (2016). Application of Garret Ranking Technique: Practical Approach, International Journal of Library and Information Studies, Vol. 6(3):135-140.

Drulson, R. (2011). A study on communication behaviour of potato growers in east Khasi district of Meghalaya. M.Sc. (Ag) thesis, COA, CAU, Imphal.

Garett, H.E. and Woodworth, R.S. (1969).Statistics in psychology and education. Vakils, Feffer and Simons Pvt. Ltd., Bombay. p. 329.

Gohil G.R., Raviya P.B., Parakhiya A.M. and Kalsariya B.N. (2016). Constraints Faced by Cotton Growers In Crisis Management of Cotton Cultivation in Gujarat, International Journal of Agriculture Sciences, Vol. 8 (25):1500-1502.

Shelke, R. D. and Kalyankar, S. P., (2004). Constraints in transfer of technologies in cotton production, Paper presented in the symposium strategies for sustainable cotton production- a global vision; held at the Univ. Agric. Sci., Dharwad from 2325th November 2004.

\section{How to cite this article:}

Ravi Goud, E., Daya Ram and Raghavendra Chowdary, K. 2018. Constraints Perceived by the Cotton Growers on the Cotton Cultivation in Kurnool District of Andhra Pradesh, India. Int.J.Curr.Microbiol.App.Sci. 7(06): 872-876. doi: https://doi.org/10.20546/ijcmas.2018.706.102 